\title{
Microbiological Control in Hospital Environment: Calibrating Enumeration of Bacteria on Flat Surfaces with Wet Swab
}

\author{
Pierre René Fotsing Kwetché ${ }^{1,2^{*}}$, Christelle Domngang Noche ${ }^{3}$, \\ O'Neal Dorsel Youté ${ }^{1,2}$, Blandine Tamatcho Kweyang ${ }^{4}$, \\ William Lelorel Nankam Nguekap ${ }^{1}$, Valère Igor Deumi Monthé ${ }^{1,2}$, Peguy Martial \\ Mbianda Tchuessi $^{1,2}$, Serge Honoré Tchoukoua ${ }^{1,3}$ and Jules Clément Assob Nguedia ${ }^{5}$ \\ ${ }^{1}$ Laboratory of Microbiology, ${ }^{2}$ School of Biomedical Sciences, ${ }^{3}$ School of Human \\ Medicine, Higher Institute of Health Sciences, Université des Montagnes Teaching Hospital; \\ Bangangté, Cameroon \\ ${ }^{4}$ Department of Microbiology, University of Yaoundé I, Yaoundé Cameroon \\ ${ }^{5}$ Faculty of Medicine and Pharmaceutical Sciences, University of Douala, Douala Cameroon
}

*Corresponding author

\section{A B S T R A C T}

The work environment in healthcare facilities is a reservoir of microbes whose presence must be controlled with appropriate tools. In order to monitor the dynamics of surface colonization in healthcare facilities and to standardize the swab-based analysis method, this work involved establishing models of calibration curve that could be used to enumerate bacteria present on

Keywords

Surfaces, Bacteria, Enumeration, Wet swabbing,

Calibration

\section{Article Info}

Accepted: 07 January 2021 Available Online: 10 February 2021 surfaces made from different type of materials. The work was conducted on glass, leather, ceramic, sanded plywood, formica and aluminum surfaces using a contextualized analysis protocol with E. coli ATCC 25922 and S. aureus ATCC 29213. Data analysis revealed that the detectable bacterial inocula varied according to bacterial and surface types. Overall, detection threshold was high for each bacterial type. The lowest detection limit was $4,360 \mathrm{CFU} / \mathrm{cm}^{2}$ for $E$. coli on glass surfaces and the highest, $860,000 \mathrm{CFU} / \mathrm{cm}^{2}$ for $S$. aureus on formica. The detection of $E$. coli was 6, 10, 27, 41, and 77 times sensitive than $S$. aureus on glass, sanded plywood, formica, aluminum and leather surfaces, respectively. This finding was similar on ceramic surfaces. In relation to surfaces, glass was the material for which bacterial detection was best since the detection thresholds were the lowest compared to other types of materials. In short, these results may justify the choice of glass as appropriate material for surfaces in several settings, in connection with cleaning and disinfection in general, but the detection thresholds recorded highlight the need to explore new techniques or improve specific aspects of the method of enumeration based on wet swabbing of surfaces.

\section{Introduction}

Health facilities in all areas throughout the world provide ecosystems that are conducive to the growth and spread of infectious agents which are often multi-resistant to antimicrobial drugs (Bertrou et al., 2000; Cavallo et al., 2002; Dancer, 2011, 2014). 
Their presence increases the likelihood of healthcare-associated infections and/or the risk of spreading hospital germs into communities (Bertrou et al., 2000; Cavallo et al., 2002; Dancer, 2014; Tchoukoua et al., 2018). For the microbial reservoir character of healthcare institution environment (Hartemann et al., 1997; Meunier et al., 2005; Dancer, 2011; Doll et al., 2018), environmental microbiology monitoring is necessary and stands to be one of the measurement tools to assess the microbiological status, the efficiency of hygiene methods useful in designing and implementing corrective measures. These controls may be carried out as part of a facility qualification procedure or may be used as investigation for educational purposes (Cavallo et al., 2002). In the quality assurance process, these controls contribute to the prevention of infections by identifying potential threats through description of the local environmental ecology in healthcare facilities, risks analysis according to the ecology of the areas concerned, human activities and exposed populations. These findings are key clues in orienting appropriate decision making as far as hospital hygiene is concerned (Boulestreau et al., 2016). The success of the process depends on a good knowledge of the area and a reliable risk analysis that takes into account, not only the sources of hazards but also the modes of exposure and the inherent patients-related risks. In addition it involves clear methodologies and anticipation of results interpretation (Bertrou et al., 2000; Cavallo et al., 2002; Boulestreau et al., 2016).

For microbiological monitoring of surfaces, one of the analytical methods used and/or suggested by some authors is based on swabbing (Bertrou et al., 2000; Boulestreau et al., 2016; Tchoukoua et al., 2018; Fotsing Kwetché et al., 2020). However, some authors report a number of factors influencing the reliability related making it difficult to assess the real surface colonization (Hartemann et al., 1997; Moor and Griffith 2002 a, b, 2007; Keeratipibul et al., 2017). Thus, for better monitoring using this method on the basis of data provided by previous authors (Hartemann et al., 1997; Moor and Griffith 2002a,b, 2007;Keeratipibul et al., 2017), a benchmark to help predicting accurately the bacterial loads based on the enumeration result subsequent to microbial culture is necessary and should be developed. The purpose of the present investigation was primarily to determine the relationship between these two parameters for a wet swabbased analysis method in order to improve the understanding of colonization of surfaces in a variety of environments, particularly in healthcare facilities. It was also to afford standardization of the swab-based analysis method according to the environment and more especially to the type of surfaces that are potential germ carriers. This was done through designing a calibration curves for the enumeration of bacteria on various types of surfaces and detection thresholds on each type of material used to build surfaces.

\section{Material and Methods}

\section{Type, location, period, population of study and administrative considerations}

This was a cross-sectional descriptive study carried out at the "Université des Montagnes" Teaching Hospital (UdMTH). It was conducted from January, $6^{\text {th }}$ through April, $24^{\text {th }}, 2020$. Prior to specimen collection and analyses, a research authorization $\mathrm{N}^{\circ}$ 2020/052/AED/UDM/CUM was provided by the UdMTH's Head and the ethical clearance $\mathrm{N}^{\circ}$ 2020/147/UdM/PR/CIE delivered by the ethical committee of the "Université des Montagnes". Bacteriological analyses were performed in the Laboratory of Microbiology of the UdMTH. 


\section{Material selection}

Surface material specimens subjected to analysis included formica, aluminum, ceramic, glass, sanded plywood and leather. The choice of these coating elements was based on their frequent use in local healthcare facilities. The unit surface explored was 25 $\mathrm{cm}^{2}$ shaped on square pieces of $36 \mathrm{~cm}^{2}$ $(6 \times 6 \mathrm{~cm})$ plates made of the above materials. They were then cleaned and sterilized prior to each use. For each type of material, manipulations were done aseptically, free from any possible contaminations.

The test protocol used was a modified version of those for previous investigations (Keeratipibul et al., 2017; Fotsing Kwetché et al., 2020), then with slight modifications.

\section{Subculture of reference strains}

A subculture of the reference bacterial strains was performed on nutrient agar incubated overnight at $37^{\circ} \mathrm{C}$. Namely, these reference strains used in all experiments were E. coli ATCC 25922 and S. aureus ATCC 29213 for Gram-negative rods and Gram positive cocci, respectively. Their chose was based on their implications in the healthcare-associated infections (Haque et al., 2018).

\section{Preparation of a bacterial suspension series}

With fresh bacterial culture, one bacterial suspension for each strain type was prepared in sterile physiological saline $(0.9 \% \mathrm{NaCl})$ within test tubes. The turbidity of the suspension was adjusted and compared with that of a McFarland standard (DalynnBiologicas, 2014). Subsequently, four successive decimal dilutions of this original suspension were performed in sterile physiological saline. For each surface type, three series of bacterial suspension were prepared according to a McFarland standard.
The serial McFarland standards increased in opacity from one series to the other.

\section{Inoculation of the experimentation support materials}

Subsequent to preparation of each bacterial suspension, $50 \mu \mathrm{L}$ of inoculum was spread on three plates/supports of each surface specimen type. Protected from dust and air flow, the inoculated plates were placed in a safety enclosure for $20 \mathrm{~min}$ at room temperature to allow smooth drying. The bacterial load spread over the surface was referred to as the "actual bacterial load".

\section{Sampling}

The sampling from each plate was done upon completion of the drying $(20 \mathrm{~min})$ by wet swabbing. Primarily, the cotton bud of the sterile swab was soaked with $120 \mu \mathrm{L}$ of sterile physiological saline $(0.9 \% \mathrm{NaCl})$. To swab, the moistened cotton was rubbed over the entire inoculated surface of the dried plate preparation with tight streaks (average 20 streaks) in two perpendicular directions (one after the other). Handled between the thumb and the middle finger with the index finger on the stem, the swab underwent a $90^{\circ}$ rotation after each half of the rubbed surface while a strong pressure (avoiding breaking the stem) was exerted to optimize the rubbing.

\section{Culture}

For each surface sample, the cotton bud of the swab was aseptically broken and transferred into $2 \mathrm{~mL}$ of sterile physiological saline in a test tube, thoroughly mixed at $2400 \mathrm{rpm}$ for 1 minute (with short stops every 5 seconds). For each bacterial suspension, two inocula of 50 $\mu \mathrm{L}$ were, aseptically, pipetted and inoculated (by spreading after placing a spotlight) on two appropriate culture media. These preparations were then incubated at $37^{\circ} \mathrm{C}$ for 24 hours. The 
bacterial suspensions were often diluted before the inoculation for a good enumeration. The agars used in this step were specific to the test strain. Namely, they were Mannitol Salt agar (Liofichem ${ }^{\circledR}$ ) for $S$. aureus ATCC 29213 and Eosin Methyl Blue agar (Liofichem ${ }^{\circledR)}$ ) for E. coli ATCC 25922.

\section{Enumeration}

After incubation, enumeration was performed and reported as colony forming unit per $\mathrm{cm}^{2}$ $\left(\mathrm{CFU} / \mathrm{cm}^{2}\right)$ in each case. These results reported were referred to as the "observed bacterial load". The conversion formula was "OBL $=40 \times \mathrm{N} \times 10^{\mathrm{d}} / 25$ ".

OBL is the observed bacterial load $\left(\mathrm{CFU} / \mathrm{cm}^{2}\right) ; \mathrm{N}$ is the $\mathrm{CFU}$ number per Petri dish; $10^{\mathrm{d}}$ is the dilution factor; 40 is the ratio of volume of extraction fluid over the volume of inoculum and $1 / 25$ the conversion factor from the number of CFU enumerated per 25 $\mathrm{cm}^{2}$ over the number of CFU per $1 \mathrm{~cm}^{2}$.

\section{Data analysis and calibration curve}

The results were recorded and treated with Microsoft Excel 2013. The Regression software version 4.1.5 was then used to generate the related calibration curves. For each surface category in this work, a least square curve was constructed from which the actual bacterial loads (ABL) on the surfaces could be estimated as a function of the observed bacterial loads (OBL).

The calibration curves were mathematically designed by the following expression " $\mathrm{y}=\mathrm{a} \mathrm{x}$ $+b$ " (where $y=A B L, x=$ OBL, $a$ and $b$ are the coefficients of the curve), and the correlation coefficient " $\mathrm{R}$ "' between the actual and observed bacterial loads, at 95\% confidence interval. The detection threshold was calculated for $1 \mathrm{CFU} / \mathrm{Petri}$ dish, i.e. about $2 \mathrm{CFU} / \mathrm{cm}^{2}$.

\section{Results and Discussion}

Protocol implementation lead to different calibration curves. Their characteristics were summarized and displayed as shown in Table 1. Overall findings revealed that the detection and enumeration of bacteria on a surface are both bacterial-type and surface-type dependent.

For some surfaces like formica, the detection threshold was very high, while on glass the value recorded was relatively low. Further details related to bacteria type and surface category are presented in Table 2. A glance through recorded data indicated that detection of $E$. coli was easier than detection of $S$. aureus. In fact, compared to $S$. aureus, isolation of $E$. coli was six folds higher on glass, ten folds easier on sanded plywood, twenty-seven folds higher on formica, fortyone folds easier on aluminum and 77 folds easier on leather. This detectability for both types of bacteria was similar on ceramic. In addition, this table reveals that $E$. coli was more easily isolatable on glass, aluminum and leather than it was on formica, ceramic and sanded plywood. S. aureus was more difficult to isolate on aluminum, leather, sanded plywood and formica than it was on glass and ceramic.

To investigate and better assess the dynamics of surface colonization in healthcare facilities and standardize the swab-based protocol, the calibration curve for the enumeration of bacteria was established and the detection of bacteria assessed. The findings recorded revealed different thresholds of detection from one bacterial type to the other and from one surface type to the other. Overall, however, the detection thresholds were high. The high thresholds highlighted a weakness in the bacterial detection with the protocol used. These results could be explained by intrinsic and extrinsic characteristics of the work 
procedure(Moor and Griffith, 2002a,b,2007; Keeratipibul et al., 2017), consistently assessed and discussed individually or in group works (Eginton et al., 1995; Li and Logan, 2004; Moor and Griffith, 2002a,b,2007; Mitik-Dineva et al., 2009; Ortega et al., 2010; Song et al., 2015; Bohinc et al., 2014, 2016; Keeratipibul et al., 2017; Le Gallou and Lepelletier, 2017).

Intrinsically, swabbing-based detection and enumeration of surface bacteria rely to key considerations which are: first, the ability of the swab material to detach microorganisms from the surface, second, their extraction from the material during removal by the extraction method, and third, the bacterial recovery (Moor and Griffith, 2002a,b, 2007). In fact, the ability to detach microorganisms influences the bacterial detection by the typology of the sampling material. In swab sampling (manual handling), the limited pressure exerted on the wooden stick of the swab uses low mechanical energy in connection with the flexible nature of the shaft which theoretically reduces the likelihood of bacterial removal from the targeted surface material. Moreover, this pressure is difficult to quantify (Moor and Griffith, 2002a,b, 2007). This limitation in quantification could justify the recommendations by some authors who advocate that only a limited number of skilled persons would perform surface swabbing. Le Gallou et al., (2017) recommend that it should ideally be done by one and the same qualified operator to ensure standardization of sample collection. However, increasing the number of specimens could reduce the likelihood of inherent errors. At the extraction step, these results could be influenced by the retention capacity of the sampling material which could subsequently be a limiting factor for bacterial enumeration (Moor and Griffith, 2002a,b, 2007). In these case, this could be justified by the fact that the cotton has a good absorption capacity compared to other materials (gauze, polyurethane foam, cellulose, sponge) used for surface sampling, but endowed with low release. Otherwise, during sampling, this material extracts large bacterial loads, a small fraction of which is released upon agitation (Moor and Griffith, 2002b, 2007; Keeratipibul et al., 2017). However, cotton swabs are the most widely used and accessible material in this context. The last point, bacterial recovery is associated with the growth capacity that extracted bacteria express on culture media. During sampling, microbial populations encompassing viable bacteria and bacteria stressed by the environment or damaged by the mechanical action of handling are extracted together. The stressed or damaged organisms are thought to be amongst factors that reduce the growth yields, expressed as low count in colony forming units (Hartemann et al., 1997; Moor and Griffith, 2002a,b, 2007). In some cases, however, this factor would have no impact. An experimental survey revealed that more than $90 \%$ of a viable E. coli inoculum that had been left to dry for 2 hours on the surface of a cutting board could not be recovered, though $75 \%$ of these cells remained viable during this drying time(Moor and Griffith, 2002a). This finding primarily suggests that viability would not have a significant role detection rates. This growth capacity may also be impacted by the type of bacterial growth medium used which may be poor or rich in nutrients (Hartemann et al., 1997; Moor and Griffith, 2002a,b, 2007). Some authors believe that the dryness of a surface is a factor that increases bacterial adhesion and would explain the difficulty in extraction during sampling. Their experiment was carried out on wet and dry stainless steel surfaces and they reported a lower detection on dry surfaces than on wet surfaces (Moor and Griffith, 2002a,b; Keeratipibul et al., 2017). Accordingly, moistening a surface before sampling or cleaning would make removal more effective. 
This could reasonably be applied during routine surface cleaning and disinfection. According to this context and to Ortega et al., (2010) sterile distilled water would be recommended for prior-sampling moistening.

Throughout the present investigation, variabilities in detection thresholds were observed, suggesting different levels of adhesion from one type of surface to the other. This tendency is likely associated with the amplitude of bacteria-surface interactions, consistent with the adhering strength. As external factor to the methodology used, it is difficult to control, but could significantly have a negative impact on the bacterial release step. This interaction/adhesion depends mainly on the inherent properties associated to bacteria (electrical charge and hydrophobicity of the envelope, adherent substances produced, size, shape, appendages, biofilm formed) and the properties of the hosting surface that include electrical charge, hydrophobicity, chemical structure, topography, roughness, organic and inorganic substrate contents on the surface, all of which can play stochastic significant role on bacterial survival and growth (Song et al., 2015).

Table.1 Characteristics of the calibration curves

\begin{tabular}{|c|c|c|c|c|}
\hline Strains & Materials & $\begin{array}{l}\text { Equation of the } \\
\text { calibration curve }\end{array}$ & $\mathbf{R}^{2}$ & $\begin{array}{l}\text { 95\% CI of the slope (a) and } \\
\text { constant (b) }\end{array}$ \\
\hline \multirow{6}{*}{ 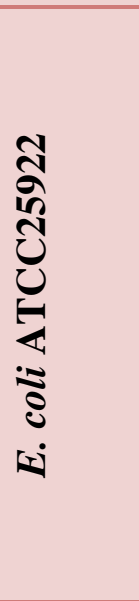 } & Aluminum & $\begin{array}{c}\mathrm{ABL}= \\
2.614 \times 10^{3} \mathrm{OBL}+2 \times 10^{3}\end{array}$ & 0.99924 & $\begin{array}{c}\text { a: }\left[2.584 \times 10^{3}-2.644 \times 10^{3}\right] \\
\text { b: }\left[-8 \times 10^{3}-12 \times 10^{3}\right]\end{array}$ \\
\hline & Ceramic & $\mathrm{ABL}=400 \mathrm{OBL}+63 \times 10^{3}$ & 0.97667 & $\begin{array}{c}\text { a: }[364-436] \\
\text { b: }\left[-128 \times 10^{3}-254 \times 10^{3}\right]\end{array}$ \\
\hline & Formica & $\mathrm{ABL}=161 \mathrm{OBL}+32 \times 10^{3}$ & 0.98504 & $\begin{array}{c}\text { a: }[153-169] \\
\text { b: }\left[-20 \times 10^{3}-84 \times 10^{3}\right]\end{array}$ \\
\hline & Glass & $\mathrm{ABL}=180 \mathrm{OBL}+4 \times 10^{3}$ & 0.99691 & $\begin{array}{c}\text { a: }[176-184] \\
\text { b: }\left[-5 \times 10^{3}-13 \times 10^{3}\right]\end{array}$ \\
\hline & Leather & $\mathrm{ABL}=721 \mathrm{OBL}+7 \times 10^{3}$ & 0.99342 & $\begin{array}{c}\text { a: }[697-745] \\
\text { b: }\left[-12 \times 10^{3}-26 \times 10^{3}\right]\end{array}$ \\
\hline & $\begin{array}{l}\text { Sanded } \\
\text { plywood }\end{array}$ & $\begin{array}{c}\mathrm{ABL}=33.5 \times 10^{3} \\
\mathrm{OBL}+12 \times 10^{3}\end{array}$ & 0.98943 & $\begin{array}{l}\text { a: }\left[32.1 \times 10^{3}-34.9 \times 10^{3}\right] \\
\text { b: }\left[-63 \times 10^{3}-87 \times 10^{3}\right]\end{array}$ \\
\hline \multirow{6}{*}{ 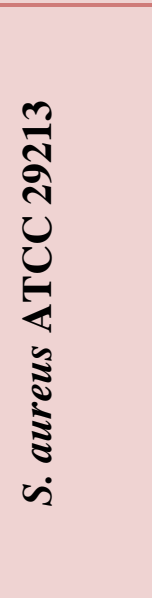 } & Aluminum & $\begin{array}{c}\mathrm{ABL}=261 \\
\mathrm{OBL}+302 \times 10^{3}\end{array}$ & 0.98793 & $\begin{array}{c}\text { a: }[246-276] \\
\text { b: }\left[-221 \times 10^{3}-825 \times 10^{3}\right]\end{array}$ \\
\hline & Ceramic & $\begin{array}{c}\mathrm{ABL}= \\
3.13 \times 10^{3} \mathrm{OBL}+53 \times 10^{3}\end{array}$ & 0.98996 & $\begin{array}{l}\text { a: }\left[2.99 \times 10^{3}-3.27 \times 10^{3}\right] \\
\text { b: }\left[-230 \times 10^{3}-336 \times 10^{3}\right]\end{array}$ \\
\hline & Formica & $\begin{array}{c}\mathrm{ABL}= \\
39 \times 10^{3} \mathrm{OBL}+782 \times 10^{3}\end{array}$ & 0.86131 & $\begin{array}{c}\text { a: }\left[32 \times 10^{3}-46 \times 10^{3}\right] \\
\text { b: }\left[-1118 \times 10^{3}-2682 \times 10^{3}\right]\end{array}$ \\
\hline & Glass & $\begin{array}{c}\mathrm{ABL}= \\
1.73 \times 10^{3} \mathrm{OBL}+23 \times 10^{3}\end{array}$ & 0.99428 & $\begin{array}{l}\text { a: }\left[1.66 \times 10^{3}-1.8 \times 10^{3}\right] \\
\text { b: }\left[-404 \times 10^{3}-450 \times 10^{3}\right]\end{array}$ \\
\hline & Leather & $\begin{array}{c}\mathrm{ABL}= \\
5.3 \times 10^{3} \mathrm{OBL}+587 \times 10^{3}\end{array}$ & 0.93152 & $\begin{array}{l}\text { a: }\left[4.7 \times 10^{3}-5.9 \times 10^{3}\right] \\
\text { b: }\left[-663 \times 10^{3}-1837 \times 10^{3}\right]\end{array}$ \\
\hline & $\begin{array}{l}\text { Sanded } \\
\text { plywood }\end{array}$ & $\begin{array}{c}\mathrm{ABL}= \\
1.31 \times 10^{3} \mathrm{OBL}+826 \times 10^{3}\end{array}$ & 0.84549 & $\begin{array}{l}\text { a: }\left[1.06 \times 10^{3}-1.56 \times 10^{3}\right] \\
\text { b: }\left[-524 \times 10^{3}-2176 \times 10^{3}\right]\end{array}$ \\
\hline
\end{tabular}

ABL: actual bacterial loads; OBL: observed bacterial loads; $95 \%$ CI: $95 \%$ confidence interval 
Table.2 Detection threshold for the analysis method used

\begin{tabular}{|l|c|c|}
\hline \multirow{2}{*}{ Materials } & \multicolumn{2}{|c|}{ Detection threshold $\left(\mathbf{C F U} / \mathbf{c m}^{2}\right) /$ bacterial type } \\
\cline { 2 - 3 } & E. coli ATCC25922 & S. aureus ATCC 29213 \\
\hline Aluminum & 7,228 & 302,522 \\
\hline Ceramic & 63,800 & 59,260 \\
\hline Formica & 32,322 & 860,000 \\
\hline Glass & 4,360 & 26,460 \\
\hline Leather & 8,442 & 597,600 \\
\hline Sanded plywood & 79,000 & 828,620 \\
\hline
\end{tabular}

CFU: colony forming unit

The detection thresholds for $E$. coli were lower than those for $S$. aureus, which, if consistent with the above development, would indicate that adhesion of $E$. coli to the tested surfaces could be less firm than adhesion of $S$. aureus. Related findings have also been reported for intact glass in previous works (Mitik-Dineva et al., 2009; Bohinc et al., 2014). In addition, the detection thresholds for $E$. coli were higher on ceramic, sanded plywood and formica than the thresholds on leather, aluminum and glass. This findings otherwise could indicate that the adhesion strength of isolates from this species would be lesser on the glass, while the detection limits for $S$. aureus would indicate that the adhesion of isolates would be less firm on ceramic tile and glass than on the other surfaces subjected to the tests. In a previous survey with $S$. epidermidis NCTC 11047 and P. aeruginosa PaWH, Eginton et al. (1995) observed that formica and stainless steel retained more bacteria than glass, in agreement with the assertion that glass is the surface with the lowest bacterial adhesion, justified by its low roughness and hydrophilicity.

Three of the above external factors will be addressed. With a regards on the electrical properties, E. coli and $S$. aureus have a negatively charged envelope (Bohinc et al., 2016). In general, positively charged surfaces are more prone to adhesion of negatively charged bacterial cells while negatively charged surfaces are more resistant to bacterial adhesion. In the environment, the presence of dead cells on a surface could reduce the surface electrical charge and facilitate bacterial adhesion. In connection with surface roughness, its effect on bacterial adhesion varies according to the surfaces type and bacteria (Song et al., 2015). However, in general, bacterial adhesion increases with surface roughness because an increase in surface roughness associates with increase in the contact area between the hosting surface and the bacterial cells (Bohinc et al., 2014; Song et al., 2015). This would explain why in the present work the detection threshold of actual bacterial loads on sanded plywood are among the highest. Otherwise, surfaces with very low level of roughness like smoother, can make bacterial adhesion difficult, as shown by authors who used glass surfaces with different roughness degrees (MitikDineva et al., 2009; Bohinc et al., 2014). This characteristic can provide protection for certain bacteria against detachment in such instances like cleaning or during sampling (Ortega et al., 2010; Bohinc et al., 2016). From a hygienic point of view, the use of smooth or very low surface roughness would be an asset for sanitation. This reduced roughness could be associated with the topography of the surface and the presence of specific designs (Song et al., 2015). The impact of surface roughness on bacterial adhesion is generally evaluated together with 
the hydrophobicity of the surface. It has also been found that this property depends on the type of surface, the level of hydrophobicity of the surface, and the bacteria (Song et al., 2015). E. coli isolates are generally hydrophilic while $S$. aureus are hydrophobic (Mitik-Dineva et al., 2009; Bohinc et al., 2014). Previous findings reported that bacterial adherence increases in strength with the level of hydrophobicity of the glass or metal oxide-coated surface ( $\mathrm{Li}$ and Logan, 2004). In general, microorganisms attach more quickly and more rapidly to hydrophobic and non-polar surfaces compared to hydrophilic materials such as some stainless steels (Moore and Griffith, 2007). In addition, this adherence strength is enhanced when the bacteria cells are hydrophobic (Bohinc et al., 2016), consistent at least part, with the findings from $S$. aureus in the present investigation.

The enumeration method implemented in the present research provided more accurate idea on colonization dynamics of targeted surfaces. The findings documented allowed better understanding of surface-bacteria interaction than previously alleged (Tchoukoua et al., 2018; Fotsing Kwetché et al., 2020). In relation to the detection thresholds and the argument made above, the choice of glass as a coating material for some environment (e.g. laboratory, hospital, food industry) work surfaces would be an asset for better sanitation. These detection thresholds could, adversely emerge as limitation in assessing the quality of hygiene in this protocol acknowledging that such exercises aim at reducing the microbial loads and the related likelihood of contamination. Overall, results from the present survey highlight the need to improve the detection and enumeration of bacteria on surfaces using a swab. Future steps to address should take into account not only the above discussed factors, but also issue of others bacterial types, mixed bacterial populations and biofilms. The work context, workload, and the cost/effectiveness/benefit combination will also be taken into account.

Data from the present investigation resulted on designation of calibration curves with characteristics which varied according to the type of bacteria and surfaces. E. coli was more easily detected compared to $S$. aureus and glass was the material for which detection was more effective. Future steps to address bacterial enumeration on surfaces will take into consideration not only the above discussed factors, but also issue of mixed bacterial populations and biofilms. The work context, workload, and the cost/effectiveness/benefit combination will also be focused.

\section{Acknowledgments}

The authors thank Robert Tchinda Soh and Gisèle Benette Tchouela for the invaluable support provided along this survey. The authors also thank the "Université des Montagnes" and their teaching hospital for their support during this survey.

\section{References}

Bertrou A, Cetre JC, Chapuis C, Guignement S, Fabry J, Hajjar J et al., 2000. Contrôles microbiologiques de l'environnement hospitalier. Vigilance environnementale. Hygiène. 8(3): 139 179.

Bohinc K, Dražić G, Abram A, Jevšnik M, Jeršek B, Nipi D et al., 2016. Metal surface characteristics dictate bacterial adhesion capacity. Int $\mathrm{J}$ AdhesAdhes. 68: 39-46.

Bohinc K, Dražić G, Fink R, Oder M, Jevšnik M, Nipič D et al., 2014. Available surface dictates microbial adhesion capacity. Int J AdhesAdhes. 50: 265- 
272.

Boulestreau H, Bousseau A, Castel O, Cavalié L, Malavaud S, Mantion B et al., 2016. Surveillance microbiologique de l'environnement dans les établissements de santé. Guide de bonnes pratiques. CCLIN. 125p.

Cavallo JD, Antoniotti G, Baffoy N, Guignement-Coudrais S, Hajjar J, Horn C et al., 2002. Surveillance microbiologique de l'environnement dans les établissements de santé. Air, eaux et surfaces. Ministère chargé de la santé. DGS/DHOS, CTIN. 78p.

DalynnBiologicas. 2014. McFarland Standerd-For in vitro use only.Catalogue No. TM50-TM60. 2p. Disponible sur: http://www.dalynn.com/dyn/ck_assets/fi les/tech/TM53.pdf

Dancer SJ. 2011. Hospital Cleaning in the 21st Century. Eur J Clin Microbiol Infect Dis. 30: 1473-1481.

Dancer SJ. 2014. Controlling HospitalAcquired Infection: Focus on the role of the environment and new technologies for decontamination - Hospital Cleaning and Decontamination. Clin Microbiol Rev. 27 (4): 665 - 690.

Doll M, Stevens M and Bearman G. 2018. Environmental cleaning and disinfection of patient areas. Int $\mathbf{J}$ of Infect Dis. 67: 52 - 57.

Eginton PJ, Gibson H, Holah L, Handley PS and Gilbert P. 1995. The influence of substratum properties on the attachment of bacterial cells.Colloids Surf B Biointerfaces. 5: 153- 159

Fotsing Kwetché PR, Kougang EG, Domngang Noche C, Youté OD, Tchoukoua SH, Yawat Djogang AM et $a l .$, 2020. Mitigating hospital infection risks at the "Université des Montagnes" teaching hospital: holistic policy to meet the challenge. WJPPS. 9(3): $518-$ 535.
Haque M, Sartelli M, McKimm J and Abu Bakar M. Health care-associated infections - an overview. 2018. Infection and Drug Resistance. 11: 2321 $-2333$.

Hartemann P, Blech M-F and Simon L. 1997. Les contrôles microbiologiques de l'environnement hospitalier. Revue française des laboratoires. 291: 43 - 47.

Keeratipibul S, Laovittayanurak T, Pornruangsarp $\mathrm{O}$, Chaturongkasumrit Y, Takahashi $\mathrm{H}$ and Techaruvichit P.2017. Effect of swabbing techniques on the efficiency of bacterial recovery from food contact surfaces. Food Control. 77: 139 - 144 .

Le Gallou F and Lepelletier D. 2017. Contrôles particulaires et microbiologiques de l'air et contrôles microbiologiques des surfaces dans les établissements de santé. EMCBiologiemédicale. 12 (4): 1-11.

Li B and Logan BE. 2004. Bacterial adhesion to glass and metal-oxide surfaces. Colloids Surf B Biointerfaces. 36: 8190.

Meunier O, Hernandez C, Piroird M, Heilig R, Steinbach D and Freyd A. 2005. Prélèvements bactériologiques des surfaces: importance de l'étape d'enrichissement et du choix des milieux de culture. Ann Biol Clin. 63(5): $481-486$.

Mitik-Dineva N, Truong VK, Malherbe F, Crawford RJ and Ivanova EP. 2009.Escherichia coli, Pseudomonas aeruginosa and Staphylococcus aureus Attachment Patterns on Glass Surfaces with Nanoscale Roughness. CurrMicrobiol. 58:268- 273

Moor G and Griffith C. 2002a. A comparison of surface sampling methods for detecting coliforms on food contact surfaces. Food Microbiol. 19: 65 - 73.

Moor G and Griffith C. 2002b.Factors influencing recovery of microorganisms 
from surfaces by use of traditional hygiene swabbing. Dairy, Food and Environmental Sanitation. 22(6):410 421.

Moore G and Griffith C. 2007. Problem associated with traditional hygiene swabbing: The need for in-house standardization. J Appl Microbiol. 103: $1090-1103$.

Ortega MP, Hagiwara T, Watanabe $\mathrm{H}$ and Sakiyama T. 2010. Adhesion behavior and removability of Escherichia coli on stainless steel surface. Food Control. 21: $573-578$

Song F, Koo H and Ren D. 2015. Effects of material properties on bacterial adhesion and biofilm formation. $\mathrm{J}$ of Dent Res. 94(8): 1 - 8 .

Tchoukoua SH, Fotsing Kwetché PR, Njonga Tchami F, Gamwo Dongmo S, Nankam Nguekap WL, Yawat Djongang AM, Simo Louokdom J et al., 2018. Observance of guidelines towards mitigating the risk of hospital acquired infections in a university teaching hospital: preliminary findings from a pilot study towards healthcare quality improvement. WJAHR. 2(4): $204-212$.

\section{How to cite this article:}

Pierre René Fotsing Kwetché, Christelle Domngang Noche, O’Neal Dorsel Youté, Blandine Tamatcho Kweyang, William Lelorel Nankam Nguekap, Valère Igor Deumi Monthé, Peguy Martial Mbianda Tchuessi, Serge Honoré Tchoukoua and Jules Clément Assob Nguedia. 2021. Microbiological Control in Hospital Environment: Calibrating Enumeration of Bacteria on Flat Surfaces with Wet Swab. Int.J.Curr.Microbiol.App.Sci. 10(02): 452-461.

doi: https://doi.org/10.20546/ijcmas.2021.1002.053 